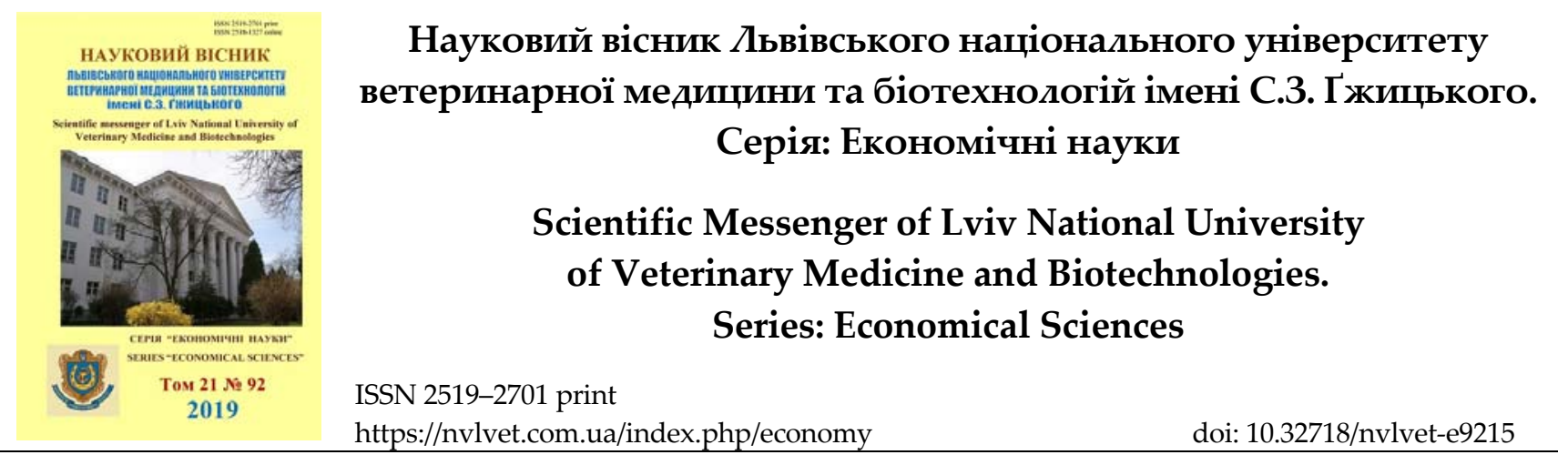

UDC $625.711(477.8)$

\title{
Development of road transport infrastructure as a factor restoration of economic potential development of rural areas in Ukraine
}

\author{
R.L. Lupak ${ }^{1}$, M.V. Kunytska-Iliash ${ }^{2}$ \\ ${ }^{1}$ Lviv University of Trade and Economics, Lviv, Ukraine \\ ${ }^{2}$ Stepan Gzhytskyi National University of Veterinary Medicine and Biotechnologies Lviv, Ukraine
}

Article info

Received 04.02.2019

Received in revised form 05.03 .2019

Accepted 06.03.2019

Lviv University of Trade and Economics, TuhanBaranovskyi Str., 10, Lviv, 79005, Ukraine. Tel.: +38-097-264-81-26 E-mail:economist_555@ukr.net

Stepan Gzhytskyi National University of Veterinary Medicine and Biotechnologies Lviv, Pekarska Str., 50, Lviv, 79010, Ukraine. Tel.: +38-097-943-55-55 E-mail: kunytskam@gmail.com
Lupak, R.L., \& Kunytska-Iliash, M.V. (2019). Development of road transport infrastructure as a factor restoration of economic potential development of rural areas in Ukraine. Scientific Messenger of Lviv National University of Veterinary Medicine and Biotechnologies. Series: Economical Sciences, 21(92), 96-100. doi: 10.32718/nvlvet-e9215

The developed road transport infrastructure is a prerequisite for the economic and social development of the territories, in particular at the level of rural communities, as it allows creating conditions for comfortable living of the population, development of business initiatives, increasing the level of local accessibility of rural areas, and their investment attractiveness. The restoration of the economic potential of rural development in Ukraine objectively requires an in-depth study of the problematic aspects, obstacles and trends in the development of road transport infrastructure. The basis of the methodological basis for the study was the position of system-structural, comparative analysis and modern concepts of the institutional economy. The problematic aspects of the development of road transport infrastructure in the rural areas of Ukraine are identified, which are related to the neglect and low efficiency of the use of the end stops of the bus passenger transport, insufficient volumes of development and updating of roadside service facilities, low quality of passenger car transport, low quality of road works on the repair, construction and eradication of road friction, low efficiency of the public administration system motor roads, destruction of road construction due to increased weight loads on vehicles and traffic. The obstacles to improvement of road transport infrastructure in rural areas of Ukraine were identified: lack of practice of liquidation or legalization of spontaneous stops, lack of investments for their modernization; lack of effective interaction between local governments and executive authorities on the organization of passenger transportation and control over their functioning; lack of experience and non-compliance with standards for the development of road service facilities; deterioration of the network of highways; progressive aging of fixed assets and rolling stock of road enterprises; understatement of the warranty terms of the use of road surface. The directions of improvement of the state policy in the field of development of road transport infrastructure in the rural areas of Ukraine have been formed, which envisage the introduction of planning practices for the construction of objects of infrastructure of road objects, creation of incentives for carriers for the development of road transport infrastructure, approval of a regional program of development of highways of local the creation of transport and construction clusters at the subregional level, the introduction of new standards and qualifications conditions for conducting tenders for repairs, engineering and architectural arrangement of highways of local importance, the formation of databases of bona fide enterprises serving the road transport infrastructure, implementation of pilot projects in the field of reforming the existing system of road management in rural areas.

Key words: rural territories, road transport infrastructure, public administration, economic potential, development.

\section{Розвиток дорожньо-транспортної інфраструктури як чинник відновлення економічного потенціалу розвитку сільських територій в Украйні}

\author{
Р.Л. Лупак ${ }^{1}$ М.В. Куницька-Іляш ${ }^{2}$
}




\author{
${ }^{1}$ Львівський торговельно-економічний університет, м. Львів, Україна \\ ${ }^{2}$ Львівський національний університет ветеринарної медицини та біотехнологій імені С.3. Гжсицького, \\ м. Львів, Україна
}

Розвинена дорожньо-транспортна інфраструктура є необхідною передумовою економічного і соиіального розвитку територій, зокрема на рівні сільських громад, адже дозволяе створити умови для комфортного проживання населення, розвитку бізнесініціатив, підвищення рівня локальної доступності сільських територій, їх інвестиційної привабливості. Відновлення економічного потенціалу розвитку сільських територій в Україні об'єктивно потребує глибокого дослідження проблемних аспектів, перешкод та напрямів розвитку дорожньо-транспортної інфраструктури. Базисом методологічної основи дослідження слугували положення системно-структурного, порівняльного аналізу та сучасні кониепиії інституціональної економіки. Визначено проблемні аспекти розвитку дорожньо-транспортної інфраструктури на сільських територіях України, які стосуються занедбаності та низької ефективності використання кінщевих зупинок руху автобусного пасажирського транспорту, недостатніх обсягів розбудови та оновлення об 'єктів придорожнього сервісу, низького рівня якості функиіонування пасажирського автомобільного транспорту, низької якості дорожніх робіт з ремонту, будівнищтва та ліквідації ямковості на автошляхах, низької ефективності системи державного управління автомобільними дорогами, руйнування дорожніх конструкцій внаслідок збільшення вагових навантажень від транспортних засобів та інтенсивності руху. Ідентифіковано перешкоди покращення дорожньо-транспортноі інфраструктури в сільській місцевості Украӥни, до яких віднесено: відсутність практики ліквідації або узаконення стихійних зупинок, брак інвестииій для їх модернізаиії; неналагодженість ефективної взаємодії органів місиевого самоврядування та виконавчої влади з організації пасажирських перевезень і контролю за їх функціонуванням; відсутність досвіду та невиконання норм щодо розбудови об'єктів дорожнього сервісу; погіршення мережі автомобільних доріг; прогресуюче старіння основних фондів та рухомого складу підприємств дорожнього господарства; заниження гарантійних термінів експлуатачії дорожнього покриття. Сформовано напрями удосконалення державної політики у сфері розвитку дорожньо-транспортної інфраструктури на сільських територіях України, щңо передбачають запровадження практики планування створення об'єктів інфраструктури дорожніх об 'єктів, створення стимулів для автоперевізників щодо розвитку дорожньо-транспортної інфраструктури, ухвалення регіональної програми розвитку автомобільних доріг місиевого значення, створення транспортно-будівельних кластерів на субрегіональному рівні, впровадження нових стандартів та кваліфікаційних умов при проведенні тендерів на ремонт, інженерне і архітектурне облаштування автомобільних доріг місиевого значення, формування баз даних сумлінних підприємств, обслуговуючих дорожньо-транспортну інфраструктуру, реалізацію пілотних проектів у сфері реформування існуючої системи управління автомобільних доріг на сільських територіях.

Ключові слова: сільські території, дорожньо-транспортна інфраструктура, державне управління, економічний потенціал, розвиток.

\section{Вступ}

Пріоритетні завдання державної політики відновлення економічного потенціалу розвитку сільських територій стосуються покращення умов та створення територій, комфортних для проживання сільського населення та розвитку бізнес-ініціатив, шляхом розбудови транспортно-логістичної, модернізації вузлових транспортних об'єктів, оновлення об'єктів придорожнього сервісу, підвищення якості та ефективності функціонування системи транспортного сполучення.

Беззаперечно, що розвинена дорожньотранспортна інфраструктура $є$ необхідною передумовою відновлення економічного потенціалу розвитку сільських територій в Україні, адже дозволяє задовольнити потреби підприємств та населення в перевезеннях вантажів і пасажирів, налагодити стабільні виробничо-коопераційні зв'язки, досягнути збалансованого просторового розвитку та підвищити рівень локальної доступності сільських територій, їх інвестиційну привабливість і конкурентоспроможність. Проте рівень розвитку дорожньо-транспортної інфраструктури сільських територій України є недостатнім, що й визначає важливість удосконалення державного регулювання у цій сфері.

Метою статті $є$ наукове обгрунтування проблемних аспектів, перешкод та напрямів розвитку дорожньо-транспортної інфраструктури у контексті відновлення економічного потенціалу розвитку сільських територій в Україні.

\section{Матеріал і методи досліджень}

У якості методологічної основи дослідження використано положення системно-структурного, порівняльного аналізу та сучасні концепції інституціональної економіки, що й визначило авторські припущення стосовно вибору та реалізації напрямів розвитку дорожньо-транспортної інфраструктури на сільських територіях.

У контексті аналіз останніх досліджень і публікацій встановлено, що проблемні аспекти і перешкоди розвитку транспорту та покращення стану доріг у сільській місцевості висвітлені у роботах таких вітчизняних вчених, як В. Бойко, В. Борщевський, 3. Варналій, І. Валюшко, Т. Васильців, В. Волошин, О. Собкевич, О. Шевченко, Я. Шевчук та інші. Водночас у міру зростання вимог до якості дорожньотранспортної інфраструктури існує необхідність пошуку нових шляхів для забезпечення сільської економіки у достатній мірі відповідними об'єктами, що й призведе до розвитку господарських комплексів та вирішення критичних проблем на селі.

\section{Результати та їх обговорення}

Відновлення економічного потенціалу розвитку сільських територій $\epsilon$ неможливе без розбудови дорожньо-транспортної інфраструктури. Так, об'єкти дорожньо-транспортної інфраструктури виконую надважливі функції, що пов'язані з розвитком підприємництва та диверсифікацією економіки, покращенням забезпеченості соціальними послугами, розвит- 
ком людського капіталу та вирівнянням таким чином просторово-територіального розвитку.

В Україні вже довгий час не вдається вирішити низку проблем для забезпечення достатнього розвитку дорожньо-транспортної інфраструктури у сільській місцевості. Про це свідчить занедбаність і низька ефективність використання автобусних станцій та кінцевих зупинок руху автобусного пасажирського транспорту. Через відсутність фінансування діяльності та збитковість більшість із них на сільських територіях України у пострадянський період припинили своє функціонування та зруйнувалися чи у кращому разі перетворилися на об'єкти стихійної торгівлі чи автостоянки.

Низька якість функціонування діючих автостанцій, вокзалів та міжмашрутних зупинок обумовлюється низьким рівнем матеріально-технічного забезпечення, моральним зносом приміщень і залів очікування, нерозвиненістю торговельно-сервісної інфраструктури, систем інформаційного та звукового забезпечення пасажирів.

Перепрофілювання та закриття автостанцій призвело до їх усунення $з$ процесу організації та координації пасажирських перевезень на міжміських і приміських маршрутах та перешкоджання створенню єдиної автоматизованої системи продажу і бронювання квитків. Причому відбувається процес збільшення кількості неконтрольованих стихійних зупинок.

Свідченням наявності гострих проблем щодо функціонування дорожньо-транспортної інфраструктури сільських територій України є недостатні обсяги розбудови й оновлення об'єктів придорожнього сервісу європейського типу для подорожуючих та автотранспортних засобів на автошляхах місцевого значення та облаштування зупинок автобусного транспорту на території віддалених сільських населених пунктів. На автошляхах між населеними пунктами відсутні в достатній кількості майданчики для стоянки транспортних засобів, приміщення для відпочинку, пункти технічного обслуговування, приймання їжі тощо. Поза іншим, у межах під'їзних шляхів до сіл відсутні спеціальні споруди та засоби, призначені для забезпечення безпечних та зручних умов руху (освітлення, технологічного зв'язку, примусового зниження швидкостi) (Vasyl'tsiv \& Boyko, 2016; Boyko, 2017).

Проблемою залишається й низький рівень якості функціонування пасажирського автомобільного транспорту та його інфраструктури. Так, на багатьох маршрутах, зокрема на віддалених від обласного центру територіях, й надалі працює багато транспортних засобів, що морально зношені або переобладнані 3 вантажних автобусів, характеризуються низьким рівнем комфортності. При цьому не всі водії мають відповідну підготовку для обслуговування пасажирів.

Невеликими є й обсяги вантажних і пасажирських перевезень автомобільним транспортом. Це обумовлено як зменшенням ділової активності, так і більшою мірою - надмірною витратомісткістю вантажних перевезень, особливо у віддалених сільських районах.

Водночас, не забезпечує виконання технікоексплуатаційних параметрів покриття і призводить до руйнування автодоріг в осінньо-зимовий період низь- ка якість дорожніх робіт 3 ремонту, будівництва та ліквідації ямковості на автошляхах загального користування місцевого значення. Причинами цього є використання морально застарілої техніки, порушення технології укладання асфальтного покриття, використання ремонтних робіт із застосуванням асфальтобетону, який важко переносить перепади температур, що особливо на гірських територіях із мінливими кліматичними умовами призводить до зменшення термінів експлуатації доріг лише до двох-трьох років.

До вказаних проблем додається низька ефективність системи державного управління автомобільними дорогами. Райавтодори на сьогодні не здійснюють роботи виключно з експлуатаційного утримання доріг, які перебувають на балансі регіональних служб автомобільних доріг, та не несуть відповідальності за стан автошляхів. Райавтодори є лише філіями дочірніх підприємств облавтодорів ПАТ “Державної акціонерної компанії “Автомобільні дороги України” та позбавлені права прийняття рішення щодо ремонту тих чи інших доріг, а отримують вказівки стосовно цього від Служби автомобільних доріг, що виступає замовником і одночасно фінансує ремонтні роботи. Регіональні філії облавтодорів проводять винятково ямковий ремонт існуючого покриття, відтак окремі ділянки автошляхів перебувають у незадовільному стані. Водночас фінансування в основному спрямоване на обслуговування дорожньої інфраструктури прилеглих територій до обласного центру, як наслідок допускається систематичне порушення нормативних міжремонтних термінів капітального ремонту дорожніх покриттів сільських територій.

На сьогодні спостерігається руйнування дорожніх конструкцій внаслідок збільшення вагових навантажень від транспортних засобів та інтенсивності руху, на які існуюча мережа автомобільних доріг не розрахована. Так, на автошляхах сільських територій Західного регіону України відсутні комплекси вагового контролю європейського зразка, а заходи збереження асфальтного покриття спрямовані винятково на обмеження проїзду великогабаритного автотранспорту дорогами, що ведуть до митних переходів (ЛьвівРава-Руська, Львів-Краковець, Ужгород-Чоп, КовельДоманове, Ковель-Яготин, Луцьк-Устилуг), міжобласного значення (Львів-Самбір-Ужгород, ЛьвівТернопіль, Устилуг-Луцьк-Рівне, Стрий-ІваноФранківськ-Чернівці, Мукачеве-Івано-ФранківськРогатин-Львів) та навколо обласних центрів. Водночас близько 90,0\% доріг спроектовані під навантаження на вісь автомобіля максимум у шість тонн, а сучасний вантажний автотранспорт має навантаження понад 10 тонн (Borshchevs'kiy \& Vasyl'tsiv, 2014; Vasyl'tsiv et al., 2016).

Крім наведених вище проблемних аспектів, існують i такі перешкоди покращення дорожньотранспортної інфраструктури на сільських територіях України: відсутність практики проведення атестацій автостанцій та ліквідації або узаконення стихійних зупинок, брак інвестицій для їх модернізації; неврегульованість інституційно-правового забезпечення у цій сфері, а саме - щодо функціонування автостанцій, процедури їх відкриття та закриття, формування взає- 
мовідносин між власниками автостанцій, перевізниками, органами державного управління, соціальної відповідальності всіх суб'єктів формування та обслуговування дорожньо-транспортної інфраструктури територій; неналагодженість ефективної взаємодії органів місцевого самоврядування, районних державних адміністрацій та обласних державних адміністрацій з організації пасажирських перевезень і контролю за їх функціонуванням. На даний час функціонування та розвиток транспортної мережі та іiі інфраструктури здійснюється без залучення органів місцевого самоврядування, вивчення реальних пасажиропотоків та техніко-економічного обгрунтування доцільності певних маршрутів. Також відсутній належний контроль за дотриманням перевізниками умов договорів про організацію перевезень, вимог трудового законодавства щодо робочого часу, режиму праці і відпочинку та впровадженням системи підготовки і підвищення кваліфікації, інженерно-технічного складу працівників транспортних підприємств.

Крім того, у багатьох регіонах України не реалізовано в повному обсязі програми щодо розвитку і оптимізації маршрутної мережі пасажирських автобусних перевезень, яка би дозволила врегулювати питання організації міжміських і приміських маршрутів на основі “районування" та використання супутникової навігації, програмних систем автоматизованого проектування й управління, оцінювання якості пасажирських послуг, перевезення пільгових категорій пасажирів та відшкодування втрат перевізників.

Спостерігається значне «затягування» процедур розробки і впровадження програм розвитку об'єктів дорожньо-транспортної інфраструктури на регіональному та місцевому рівні. Прийнята у 2010 р. Транспортна стратегія України на період до 2020 р. не поширилася в конкретних програмних документах на субрегіональному рівні. Зокрема, у таких документах не враховуються потреби в розбудові й оновленні об'єктів дорожнього сервісу та облаштуванні зупинок автобусного транспорту в сільських населених пунктах, зокрема депресивних.

Можна констатувати, що на сільських територіях України практично відсутній досвід щодо ефективної експлуатації та розбудови об'єктів дорожнього сервісу. Зокрема на сьогодні відсутня практика планування розміщення об'єктів сервісу вздовж автомобільних доріг, неврегульовані взаємовідносини між власниками об'єктів сервісу та Державною службою автомобільних доріг щодо виконання належних технічних нормативів, існують труднощі в отриманні дозволів суб'єктами підприємницької діяльності на розміщення, будівництво, реконструкцію, функціонування та прослідковується неузгодженість окремих правових питань у сфері розподілу землі.

Водночас збудовані зупинки за часів Радянського Союзу в сільських населених пунктах не відповідають сьогоднішнім особливостям пасажиропотоків (поширенню стихійних місць посадки і висадки пасажирів) та не враховують схеми існуючої маршрутної мережі приміських і міжміських пасажирських перевезень.

Суттєвою перешкодою інноваційного розвитку логістичної інфраструктури сільських територій є й брак розгалуженої системи транспортно-логістичних центрів. Незважаючи на те, що Волинська, Львівська та Закарпатська області розташовані поблизу кордону, на території прикордонних районів немає жодного логістичного центру європейського зразка. Всі логістичні центри, які працюють, - це маленькі приватні спеціалізовані склади 3 обмеженими функціональними можливостями. Тільки у 2010 р. було відкрито логістичний центр “Захід Ресурс” у м. Городок з метою покращення роботи відділу митного контролю Львівської митниці, але його потужності не достатні для реалізації виробничого потенціалу регіону. Відкритий у 2009 р. на території Волинської області логістичний центр “Волиньтабак” також не забезпечує транзитні потреби вітчизняних підприємств, оскільки належить до класу “В” та розміщений за 100 км від кордону (Voloshyn et al., 2015; Varnaliy et al., 2017).

Внаслідок цього спостерігається погіршення мережі автомобільних доріг (в основному через відсутність належного фінансування дорожніх робіт з ремонту і експлуатаційного утримання). За останнє десятиліття обсяг фінансування не перевищував 50,0\% від мінімально необхідної потреби в ремонті та утриманні мережі автомобільних доріг.

Інша перешкода це прогресуюче старіння основних фондів та рухомого складу підприємств дорожнього господарства, а також низька продуктивність асфальтобетонних заводів, що не дозволяє забезпечити потреби дорожніх організацій в основному ресурсі. Облавтодори у своїй діяльності використовують техніку, нормативний термін роботи якої вже закінчився.

Щодо дорожньо-транспортної інфраструктури як чинника відновлення економічного потенціалу розвитку сільських територій в Україні, то видається доцільним спрямувати заходи органів державного управління на подолання таких проблем як:

- порушення термінів прийняття базових нормативно-правових документів щодо розмежування повноважень із питань будівництва та експлуатаційного утримання автомобільних доріг, перерозподілу і передачі фінансування. Після затвердження Концепції реформування системи державного управління автомобільними дорогами у 2008 р. не внесено необхідного обсягу змін до деяких законодавчих актів України (Закону України "Про місцеві державні адміністрації”, Закону України “Про автомобільні дороги”), що перешкоджає ефективній розробці і реалізації регіональних цільових програм розвитку дорожнього господарства та пасажирських перевезень автомобільним транспортом (Vlasiuk, 2016);

- заниження гарантійних термінів експлуатації дорожнього покриття. У країнах СС будівельні організації підписують гарантійні зобов'язання строком до десяти років, згідно з якими підрядник ремонтує дорогу за свій рахунок у разі виходу їі з ладу за цей час. Загалом по Україні компанії-підрядники надають гарантію на дорожнє покриття не більше ніж на три роки за умов належної експлуатації. Проте і за такого гарантійного терміну не зберігається висока якість дорожнього покриття. Так, на трасі Київ-Чоп територією гірських районів Львівської та Закарпатської областей руйнується дорожнє полотно майже так 
само швидко, як і на “старих шляхах". Більше того, за умов катастрофічного погіршення автошляхів на сільських територіях західної України не фіксувалося жодного випадку, коли підрядника примусово змушували проводити ремонт за власний рахунок (Vasyl'tsiv \& Lupak, 2018);

- відсутність ефективного фінансового контролю за використанням державних коштів, призначених на ремонт та утримання автомобільних доріг, розвиток дорожньо-транспортної інфраструктури;

- низька ефективність реалізації державних програм з розвитку дорожньо-транспортного комплексу, досягнення їх відповідності європейським стандартам;

- обмеженість практики залучення інвестиційних ресурсів для розвитку дорожньо-транспортної інфраструктури сільських територій Західного регіону України на умовах державно-приватного партнерства.

\section{Висновки}

За результатами аналізу проблем та перешкод розвитку дорожньо-транспортної інфраструктури на сільських територіях України є підстави стверджувати, що напрямами удосконалення державної політики у цій сфері є:

- проведення інвентаризації діючих автостанцій та виявлення на іiі основі необхідності будівництва нових чи реконструкція діючих, передусім 3 метою відновлення ролі автостанцій в організації процесу пасажирських перевезень та його подальшої модернізаціï;

- поступове впровадження автоматизованої системи продажу квитків із використанням інтернеттехнологій, запровадження практики формування баз даних пасажиропотоків, єдиної інформаційної системи управління транспортним обслуговуванням пасажирів;

- запровадження практики планування створення об'єктів інфраструктури дорожніх об'єктів, які необхідно створити на автошляхах віддалених сільських територій та розробка механізмів (передусім через державно-приватне партнерство) залучення на ці цілі коштів інвесторів;

- формування стимулів (економічних та організаційних) для автоперевізників щодо розвитку дорожньо-транспортної інфраструктури та іiі об'єктів на сільських територіях;

- ухвалення регіональної програми розвитку автомобільних доріг місцевого значення, де істотна роль буде приділена розвитку дорожньо-транспортної інфраструктури сільських територій;

- $з$ метою активізації логістичних потоків, розбудови і модернізації транспортно-складської та інформаційної інфраструктури дорожнього господарства у сільській місцевості;

- впровадження нових стандартів та кваліфікаційних умов при проведенні тендерів на ремонт, інжене- рне і архітектурне облаштування автомобільних доріг 3 метою забезпечення прозорості проведення конкурсів, визначення можливостей підприємств та їх цінової політики;

- формування баз даних сумлінних підприємств будівельно-монтажних, транспортних, обслуговуючих сільську дорожньо-транспортну інфраструктуру;

- ініціювання сільськими і селищними радами перед відомчими та державними органами влади реалізації пілотних проектів у сфері реформування існуючої системи державного управління автомобільними дорогами на сільського значення.

Перспективи подальших досліджень стосуються визначення групи заходів та інструментів для реалізації запропонованих напрямів удосконалення державної політики розвитку дорожньо-транспортної інфраструктури на сільських територіях України, які становитимуть базову основу для розроблення методичних рекомендацій регіональним органам влади у вирішенні проблем інфраструктурного забезпечення відновлення економічного потенціалу сільських територій.

\section{References}

Borshchevs'kiy, V.V., \& Vasyl'tsiv, T.H. (2014). Strategic Priorities and Mechanisms of Innovative Development of Rural Territories of the Western Region of Ukraine. Obverse, Lviv (in Ukrainian).

Boyko, V.V. (2017). Priorities and tools of rural development in the system of economic security of Ukraine. NNVK “ATB”, Lviv (in Ukrainian).

Varnaliy, Z.S., Lupak, R.L., \& Rudyk, S.A. (2017). Means of stimulation of small business development in rural areas in the system of state policy of overcoming the disproportions of economic security of Ukraine. Visnyk of Lviv Trade and Economic University, 53, 5-9 (in Ukrainian).

Vasyl'tsiv, T.H., \& Boyko, V.V. (2016). Areas and means of development of rural areas in the context of strengthening the socio-economic security of Ukraine. Liga-Press, Lviv (in Ukrainian).

Vasyl'tsiv, T.H., \& Lupak, R.L. (2018). Strategy and means of convergence of the social security system of Ukraine and the EU in the process of European integration. NNVK “ATB”, Lviv (in Ukrainian).

Vasyl'tsiv, T.H., Lupak, R.L., \& Il'chuk, O.O. (2016). Areas of increasing investment attractiveness of the border areas of the western regions of Ukraine. URL: http://lv.niss.gov.ua/public/File/1/AZ\%20Invest\%207. 10.14.pdf (in Ukrainian).

Vlasiuk, O. (2016). System transformations of the national economy: challenges and expectations. Publishing House, Bydgoszcz, Poland.

Voloshyn, V.I., Vasyl'tsiv, T.H., \& Lupak, R.L. (2015). Directions of stimulation of small business development in peripheral territories of western regions of Ukraine. URL: http://www.niss.gov.ua/articles/1290 (in Ukrainian). 